\title{
都市住宅に於ける地域性に関寸る研究
}

（都市社会に於ける住宅型式と人間関係に就いての研究の内一建築関係の調査一）

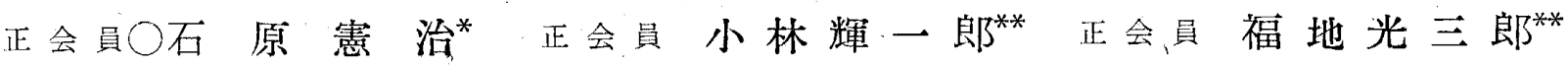

§1. 研究目的この研究虫都立大学社会学教室岡邦 雄教授委委員長として社会学研究室の小山、磯村両教 授、大塩、小山両助教授、住谷氏、建築学研究室の石 原、小林、福地の各氏が参加して、社会学研究室と建築 学研究室との共同調查の形で企画し研究したものであ る。課題の意図は地域社会生活に於ける人間関係の諸特 性を特江住宅型式を分類指標として解析しようとするる のである。建築学研究室では、これ等の主要目的の中で 特に、次の 3 点の諸側面の解析行重点を置いて調査した。

(1) 旧来行われて居る住居水準という指標を、その水 準決定に動く要素を現象的側面からのみ把えるのでな く、住宅活居する人の住生活的な内容（意欲、意見、 期待、態度等）も同時他光て、その相互関係が都市で の地域的な諸性質をぞの様に規定しているかを調べる。

(2). 住い方の行動決定飞働く、価值の方向づけ（VaIue-orientation) の在り方を都市住宅の 地域性格形成と の関聯の中で追求する。即ち、住宅の計画操作技術とし て問題となつて居る、(1) 生活能率的な問題である椅子 店式生活の值価の方向づけ、電化拖設の取入れ方の価値 の方向づけの問題、(2) 生活感情的な問題である慣習性 （床）間、畳式生活）座敷や客間につくられる格式等へ の価值の方向づけ、（3）家相問題と格式との関係、(4) 機能分化的な問題である食寝分離、就葠分離、相互接触 を必要とする空間性の中情生ずる分離化形成の性格等へ の価值の位置づけ方、(5) 設計された住宅の居住性（広 サ、動的 (配置) 室内機能) 飞対する居住者の評価・判 断・期待の仕方の椂相を把兄今後計画操作を営む際に生 ずる問題（計画技術との関聯）(3居住者にからむ人間関 係（特に建築業者との関係、態度、判断の仕方、建築関 係者との結合の仕方の問題) である。

\section{§2. 調査方法}

調 查日：A：1956.5.14 6.17 $0: 9.21 \sim 10.1$

調查数: $A=304$ 户 $0=338$ 户

調查方法：調查予定地域内皆階調查<阿佐ヶ谷四丁 目・大島七丁目>

第二次調查として Sampling 飞依つて、(1) 意欲・態 度・意見等の信頼性を確認する調查操作上の問題、(2) 調査員行動営理上の問題、(3) 回答者飞からむ相手方の 情況（特に主婦回答に㗢く、しゆとの関係）飞依る偏倚
性、不確らしさの問題等を焦点として進めた。本調査以 前注、予備調査として高橋七丁目、阿在ヶ谷四丁目を 選択して皆階調査に依つて本調查を進めるに必要な情報 獲得を行つた。

§3. 調查地域の概況 阿佐ヶ谷地区は戦時中强制疎 開にあつた地域と戦前からずつと居住して居る地域とが あり、戦後は他の地域から流れ込んで来た人が多く、特 飞私営アパートが多く建設されて居る。又会社・銀行家 庭寮も多く勤人が大部分である。居住者の職業分布は、 経営管理職が $14 \%$ 、専門技術職が $14 \%$ 、一般職員が $32 \%$ として第一位を示めるに対し工鉱業労務者が 1.4 \%である。これに 対し大島地区は、戦災や強制蹯開に 全地域が会つたのであるが、戦後、それ等の大部分が移 転した新小岩方面が隆盛した為湔居住地へ戻つて来た 人が少く、殆えど全部他の地域から移住して来たものが 多く、その居住経過が一応戦前と戦後とで切り離されて 居る形である。職業分布としては、工鉱業労務者が 28 $\%$ で第一位であり、それ次いで自家商業・サービス 業主、 $(12 \%) 、$ 自家 鉱工業主 $(15 \%)$ で、一般職貝が $12.2 \%$ ：経営管理職が $3.5 \%$ である。

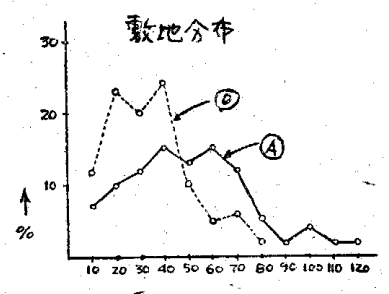

垺 $\longrightarrow$

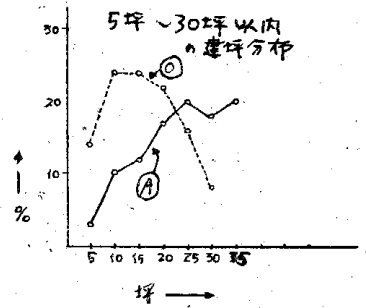

嵝 $\longrightarrow$

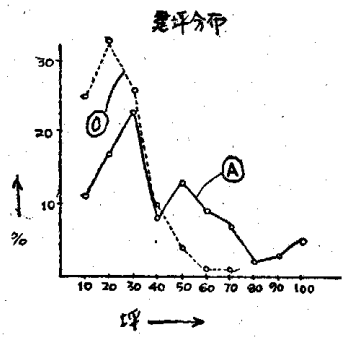

部绕数分布

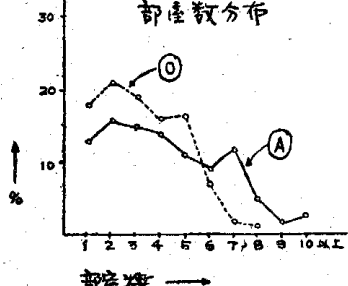

部害 $\longrightarrow$
第 1 図

\section{§4. 調查対象に就いて}

(1) 調查家屋の内容

これは宅地と家屋の所有関係と地域別に見たものであ る。

§5. 住宅構造や施工の上に見られる地域特性に就い 


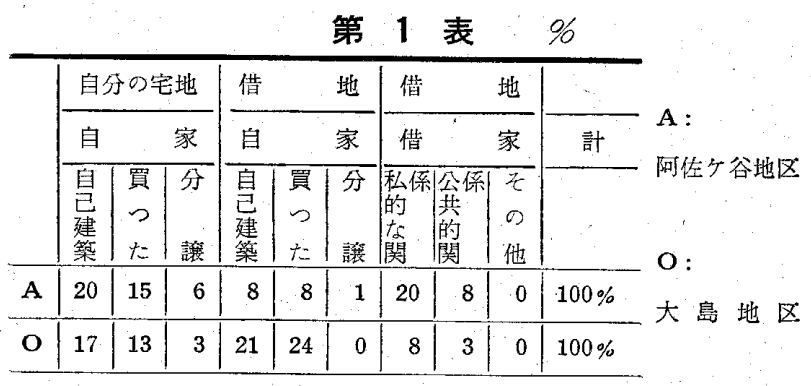

第 2 表 建赖率分布

\begin{tabular}{|c|c|c|c|c|c|c|c|c|c|c|c|}
\hline & \begin{tabular}{|l|l}
$10 \%$ \\
以下
\end{tabular} & $\begin{array}{ll}11 & \\
& 20\end{array}$ & $\stackrel{21}{\sim 30}$ & 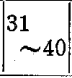 & $\mid$\begin{tabular}{l|}
41 \\
$\sim 50$
\end{tabular} & $\stackrel{51}{\sim 60}$ & \begin{tabular}{|l|}
61 \\
$\sim 70$
\end{tabular} & ${ }^{71} \sim 80$ & \begin{tabular}{|l|}
81 \\
\end{tabular} & $\mid$\begin{tabular}{l|}
$90 \%$ \\
以上
\end{tabular} & 計 \\
\hline A & 1 & 2 & 2 & 13 & 21 & 37 & 20 & 3 & 0 & 2 & 100 \\
\hline $\mathrm{O}$ & 0 & 0 & 3 & 4 & 6 & 25 & 30 & 20 & 6 & 8 & 100 \\
\hline
\end{tabular}

て 具体的には第一表を見ると判る様に結論的なるのを 挙げるとA地区とO地区とでは次の栐な地域差が摘発し 得た。(1) A地区はO地区に比べ板張り、モルタル仕上 が多い。(2) 閒就いては (有) が多く、その構造方法 も門柱・門屝ときちんとあるのが目立つてAに多い。 （3）台所就いてはAが家屋内に台所施設（流し）が多 いのにOが家屋外にあるのが目立ち、特に共同施設とし て給水関係を処理して居るのが目立つて多い。(4) 家屋 外への排水の仕方はAでは暗溝的施設が多い:のに比べ0 は開溝的な施設が多いのが特色である。

\section{\$6. 各種の居住性に対する価值づけの方向の地域性}

ここでは居住者の持つ Value Orientation 形成の地 域特性の様相を§1の (3)の（1）（5）迄と（3) を焦点と して追求したものである。

（1）椅子座式生活に対する価値の方向づけを把える 為に“その様な生活をした方が良いか”という対決的な 立場で問題を投げかけて反応を調べる Dynamic 的な調 查を取つた。これに依つて機能的な生活技術の変革に対 する相手方の持つ態度の価值づけを追求したが、特に今 日の生活が家庭外では立体的な生活や椅子式生活を為さ れる機会が多いのに対し家庭内での居住の仕方が睤座式 な生活様式を営む場合が多い現実に目を向けて問題を投 げかけて、今後の生活機能の基濋的要素のつである椅子 式生活の価值づ讨の方向を見い出そうとする意図であ る。

\section{第 3 表 $\%$}

\begin{tabular}{|c|c|c|c|c|c|c|c|}
\hline & & $w$ & $\begin{array}{l}\text { 宸いとは } \\
\text { 想はない }\end{array}$ & 悪 & $w$ & $\begin{array}{l}\text { わからな } \\
\text { W }\end{array}$ & えの他 \\
\hline A & & 45 & 14 & & 7 & 7 & 27 \\
\hline 0 & & 37 & 23 & & 19 & 4 & 16 \\
\hline
\end{tabular}

この結果の良いと答えたものの理由を内容分析的に調 ベ、解析を准めて見ると、賛成するるのが4つの Categoly に分たれて居る。(1) 全幅的に賛意を示するの（能 率的、生活に便利だから、衛生的・清潔的だから）が $\mathrm{A}=43 \% \mathrm{O}$ が $36 \%$ であり、(2) 和洋折㯖的立的で賛意 を示するの $\mathrm{A}=16 \% \quad 0=24 \%$ であり、(3) 特定の住機
能を取り上げて賛意を示するの（Aでは、居間 $=24 \% 、$ 食堂 $=36 \%$ 、葠室 $=27 \%$ 、応接間 $=4 \%$ 、その他 $=9 \%$ て ある。但し A 全体としては 31\%である。Oは少く（O $=9 \%$ で殆んど食堂、それも上層に属する地区の人であ るが亦特に店との関係で作業場（現在畳の上で作業して 居るもの）使用者の為の 食堂等が目立つ）(4)賛意を示 乙ても理由を聞くど、批判的賛意を上げるるの、 $\mathrm{A}=7$ $\%, \mathrm{O}=28 \%$ 、その他上の (4) の Categoly K分離出来 ないのが $\mathrm{A}=2 \% \mathrm{O}=3 \%$ である。この事から、は つきり地域性を規定する住意識特性が伺われる。

次、良いとタ想わないという層の意見は A, O とも有 意差なく、大体意見はく習慣上： $\mathrm{A}=37 \% ， \mathrm{O}=42 \%$ > <落つかない: $\mathrm{A}=21 \%, \mathrm{O}=18 \%$ >,くタ、ミの方が良 W $\mathrm{A}=15 \%, \mathrm{O}=21 \%>$ 、<和洋折表七して $\mathrm{A}=28 \%$ $\mathrm{O}=15 \%><$ そ他： $\mathrm{A}=8 \%, \mathrm{O}=4 \%>$ である。良 いと答えたものが、能率的な立場で判断して居るのに、 良いとは思わないという人は習慣的なもので判定を下し て居る。それを更に悪い首に就いて内容分析すると、明 らか生活感情的（落つかない、習慣、親しみ易い）立 場で判定を下して居る事が摘発出来た。

（2）客間とか格式のある座敷を無くした方が良いで しようかと問題をぶつける事に依つて、相手側の意図す る問題解明のより所を把える Dynamic 的追求を試みた 結果方次の表である。これは Value Orientation の主 要な体系である文化体系を居住という立場から把宎様と

第 4 表 $\%$

\begin{tabular}{|c|c|c|c|c|c|c|c|c|c|}
\hline & 良 & & \multirow{2}{*}{$\begin{array}{l}\text { ま岕良 } \\
\text { 心 }\end{array}$} & \multirow{2}{*}{$\mid \begin{array}{l}\text { 良い之 } \\
\text { な想は } \\
\text { な }\end{array}$} & \multicolumn{3}{|c|}{ 無くしてはいけない } & \multirow{2}{*}{$\begin{array}{l}\text { tot. } \\
\text { th }\end{array}$} & \multirow[b]{2}{*}{ 計 } \\
\hline & \begin{tabular}{|l} 
理由莫場合 \\
\end{tabular} & 理由 & & & 理由) & $\begin{array}{l}\text { 理由 } \\
\text { i }\end{array}$ & $\mid \begin{array}{l}\text { 曖味な } \\
8 の\end{array}$ & & \\
\hline $\mathrm{O}$ & 13 & 18 & 15 & 11 & 13 & 6 & 2 & 17 & $100 \%$ \\
\hline $\mathbf{A}$ & 9 & 8 & 13 & 20 & 26 & 8 & 0 & 5 & $100 \%$ \\
\hline
\end{tabular}

するものである。

この結果、生活改良をして行く形成過程での精神的な 生活技術手段の床の間問題は、Aでは良いという層が 31\% その内、はつきり理由をあげて居るものが $13 \%$ で あるのに対し、Oでは無くしては不可ないが 34\%で特 飞理由をあげて居るのが $26 \%$ も方。(有意差検定 $\left.P_{r}\left\{\chi^{2}>x_{0}{ }^{2}\right\}=0.5 \%\right)$ 特にこの様な床の間に関する問題 は、色々のマス・コミ索媒介として多くの人々に伝達さ れて居る問題で、都市生活者の住意識調查には常にマス ・コミとの関係の仕方も同時に扱つて行かなくてはなら ない。即ち、合理化への手段として人々の住意識の中に 働きかけて行く事に依つて大薪の受け方を大きく別々の 首に分化させて居る。即も 1 方は積極的にマス・コミと の関係を表面に出して、賛成の理由に新聞や雑誌で云つ てるからとか、特にAで腫䭾な生活は止めるとか、簡 単な合理的生活をとかる挙げて居るが、Oでは経済的に 考えられないからが圧侄的に多い。他方然くしてはいけ ないという意見の内容分析を進めると、A，O とも共通 
な生活感情的立場（落ちつきがない： $\mathrm{A}=31, \mathrm{O}=41$ 、 気分が落つける: $A=9, O=7$ 、習慣上 $: A=13, O=$ 10、接客関係: $\mathrm{A}=27, \mathrm{O}=23$ 、その他: $\mathrm{A}=20, \mathrm{O}=$ 19 (乞の内、華道的な関係でが 12) で部屋の扱い方を 進める際、特に床の間の問題が大きく浮び上つて来る。

(数值はすべて\%で示す)

（3）電化設備の受け入れ方に関しては、

第 6 表

\begin{tabular}{|c|c|c|c|c|c|}
\hline & 良 & 京良い & 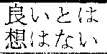 & わからない & その他 \\
\hline A & 83 & 2 & 3 & 3 & 9 \\
\hline $\mathrm{O}$ & 73 & 3 & 8 & 3 & 28 \\
\hline
\end{tabular}

これは（2）の精神的な生活技術の変革に対決した機 械的な生活技術の改革に対しての受け入れ方を追求した ものであり大体同じ傾向家示して居る。 $P_{r}\left\{x^{2}>x_{0}{ }^{2}\right\}=$ 0.95

(4) 居住機能に対する評価のされ方

第 7 表 $\%$

\begin{tabular}{|c|c|c|c|c|c|c|c|c|c|}
\hline & & & & 0 & & & & & 10 \\
\hline \multirow{3}{*}{ 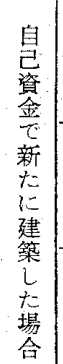 } & 広 & 別に感しない & $\begin{array}{l}4 \\
2\end{array}$ & $\begin{array}{r}7 \\
84 \\
3\end{array}$ & \multirow{3}{*}{ 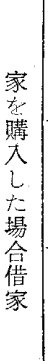 } & 広 & 別に感じない & $\begin{array}{l}77 \\
28\end{array}$ & $\mid \begin{array}{r}3 \\
56 \\
41\end{array}$ \\
\hline & 配 & $\begin{array}{l}\text { 便 利 } \\
\text { 不 便 } \\
\text { 別に感じない }\end{array}$ & 33 & $\begin{array}{l}30 \\
51 \\
19\end{array}$ & & 配 & $\begin{array}{l}\text { 便 利 } \\
\text { 不 便 } \\
\text { 別に感じない }\end{array}$ & $\begin{array}{r}5 \\
77 \\
28\end{array}$ & 15 \\
\hline & $\begin{array}{l}\text { 部 } \\
\text { 歷 } \\
\text { 能 }\end{array}$ & $\begin{array}{l}\text { 良 } \\
\text { 不 便 } \\
\text { 判らない }\end{array}$ & 52 & $\begin{array}{l}29 \\
30 \\
41\end{array}$ & & $\begin{array}{l}\text { 部 } \\
\text { 㙨 } \\
\text { 能 }\end{array}$ & $\begin{array}{l}\text { 良 } \\
\text { 不 便 } \\
\text { 判らない }\end{array}$ & $\begin{array}{r}17 \\
76 \\
8\end{array}$ & 62 \\
\hline
\end{tabular}

（5）食寝分離化への価值づけのされ方：質問は食事 する部屋と寝る部屋とは別々持つた方が良いか？内 容分析の結果：Aでは清潔、衛生的で良いが圧倒的であ

第 8 表 $\%$

\begin{tabular}{|c|c|c|c|c|}
\hline & 良 & $\therefore$ & 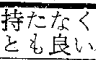 & $\begin{array}{l}\text { क力からな } \\
6\end{array}$ \\
\hline $\mathbf{A}$ & & 90 & 1 & 9 \\
\hline o & & 74 & 21 & 5 \\
\hline
\end{tabular}

り、Oで持たなくとも

良いという層の大部分

は狄小住宅で、子㤨が 大きい時は食葠分離よ

りも就得分離が優位になり易いからである。

（6）相互接蝕を必要とする空間の中生ずる分晟化 形成の性格に就いて：食事する部屋と団らえする部屋と

第 9 表 96

\begin{tabular}{|c|c|c|c|}
\hline & 良 & $\begin{array}{l}\text { 列々にしな } \\
\text { くをも良い }\end{array}$ & $\begin{array}{l}\text { क力 } 5 \% \\
\text { w }\end{array}$ \\
\hline $\mathbf{A}$ & 24 & 62 & 10 \\
\hline 0 & 39 & 57 & 4 \\
\hline
\end{tabular}
を別々洔つた方が良 いですか？の質問に 対して、内容分析の結 果 $A, O$ とも食後の団

らん、食事の析を利用して活し合うからが殆えでである が、特沉良い”の場合の理由は団らんが接客機能々結 びついて判断される事で多い。この䆩問に於て大きな特 色梳、良いと答光た人の内容分析を進めると、併用住宅 居に多く、又職業的に注由業関係の人に多くの回答が あつた。特に別々にしなくとも良いと回答した人は、そ の内容分析の結果、食後江団らえ（相手方は話し合う機 会を指す）をするのが好むしいからという事が殆んぞ
で、この事から食事、団らんの住い方の性格が浮び上つ て来る。

（7）その他に一部屋で違つた便い方を一緒にして居 第 10 表 \%

\begin{tabular}{|c|c|c|c|c|}
\hline & 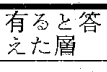 & $\begin{array}{l}\text { 無い答 } \\
\text { 管た層 }\end{array}$ & 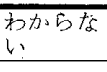 & th \\
\hline A & 9 & 75 & 16 & \\
\hline 0 & 35 & 53 & 14 & ito \\
\hline
\end{tabular}

その場合、“有る”と回答した酋の使い方の内容分析 を進めて見ると、

第 11 表 $\%$

\begin{tabular}{|c|c|c|c|c|}
\hline 使 い方 & $\begin{array}{l}\text { 洎 } \\
\text { 㱜 }\end{array}$ & $\begin{array}{l}\text { 夏 } \\
\text { 战 }\end{array}$ & 多い回答 & 特殊な回答 \\
\hline 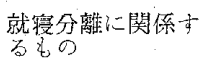 & 41 & 48 & 居間と寝㝨・寝室と子 & 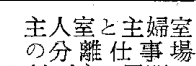 \\
\hline 食事分離 & 26 & 20 & 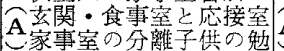 & 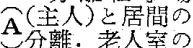 \\
\hline 接容分離 & 7 & 21 & 強部豦游場分離主人任 & 分離、部屋の数 \\
\hline 子供室分離 & 15 & 4 & 事室の分離 & 欲 \\
\hline $\begin{array}{l}\text { 風呂場之洗濯場の } \\
\text { 離 }\end{array}$ & 5 & 0 & 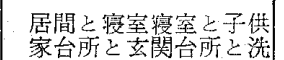 & $\begin{array}{l}\text { 老人夫婦乞の就 } \\
\text { 謾分離 }\end{array}$ \\
\hline 主婦室 & 4 & 0 & $\mid$ & \\
\hline 主人室。 & 2 & 2 & 㔚主主人室分離 & \\
\hline その他 & 10 & 4. & & \\
\hline
\end{tabular}

以上、現在一部屋で違つた使い方を一緒にして居る機 能は $\mathrm{A}, \mathrm{O}$ と夕居閏的な機能（家事・団らえ・食事）と 就寝機能を別けたいという事と、接客に関する事柄で居 間と接客空間とを分離したがるのがるのが建坪の小さい 住宅に殆んど目立つて多い。上図の欄は、その内多い場 合上特殊な場合との具体的なるのを挙げたのである。

\section{\$7. 家相への態度と格式に対する取扱い方との関聯} 性

（1）家相と格式に対する判断のされ方：

ここでは、家を新築や改築をなさる時に家相をどう考 えますか？という質問項目と、家の座教（客間）とか 玄関構え等の家のつくりの格式を新築する場合、考光に 入れるかどうかの質問項目をクロスした所、以下の結果 になつた。両反応 patternの有意差は認められなかつ た。 $\left(P_{r}\left\{\chi^{2}>\chi^{2}\right\}=0.75\right)$ 而し、雨方とも考学ないとい う首は $\mathrm{A}$ とOの間で差が見られた。 $\left(P_{r}\left\{\chi^{2}>\chi_{0}{ }^{2}\right\}=0.10\right)$ 亦特に家相は考えないが、格式は考えるという答をした

第 12 表

(O) 地区: $P_{r}\left\{\chi^{2}>x_{0}{ }^{2}\right\}=0.50$

\begin{tabular}{|c|c|c|c|c|}
\hline 格现 家相 & 考劣 る & 考えない & わからない & 計 \\
\hline 考 克 る & 72.2 & 7.1 & 2.5 & 81.7 \\
\hline 考元ない & 5.1 & 5.4 & 0.3 & 10.8 \\
\hline わからない & 2.2 & 1.6 & 3.2 & 4.0 \\
\hline 計 & 79.5 & 14.1 & 6.0 & 100 \\
\hline
\end{tabular}

(A) 地区: $\boldsymbol{P}_{r}\left\{\chi^{2}>\chi_{0}^{2}\right\}=0.70$

\begin{tabular}{|c|c|c|c|c|}
\hline 格式家相 & 考之る & 考えない & わかららい & 計 \\
\hline 若学 る & 74 & 1.5 & 2.1 & 77.6 \\
\hline 考元ない & $\dot{4}$ & 10.6 & 0 & 11.0 \\
\hline わからない & 3 & 0 & 3.0 & 6.9 \\
\hline 計 & 81 & 12.1 & 6.6 & 100 \\
\hline
\end{tabular}


ものが○とAの間で差が見られて、その 第 13 表

内容分析を追求した所、その内容を規定 する条件は○で“経済的な理由で家相家 相と云つて居られないというのが多く、 その意見の大部分が建売住宅の狄小住宅 飞居住する人に多い。Aの場合は、中流 程度の勤め人䅉に集中し、迷信であると 家相を規定するが、生活感情的には、床 の間の必要性を背定した㜿で、この様に 居住者の内容を追求する事々依つて、都 市住宅の居住性の地域差が把党られ、そ の背後には社会的階層という大きな要因

\begin{tabular}{|c|c|c|c|c|c|c|c|c|}
\hline 関傒 & & 大 工 & $\begin{array}{l}\text { 建築請負 } \\
\text { 羓 }\end{array}$ & $\begin{array}{l}\text { 設計事ム } \\
\text { 所 } \\
\text { (設計家) }\end{array}$ & $\begin{array}{l}\text { 役所関係 } \\
\text { 会社営膡 }\end{array}$ & 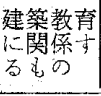 & 家具屋 & その他の業種 \\
\hline \multirow{2}{*}{ 本 人 } & A & $3(6.6)$ & $4 \quad(1)$ & 13 (2) & $2(0.5)$ & $\begin{array}{ll}0 & (0)\end{array}$ & $1(0.2)$ & \multirow{2}{*}{$\begin{array}{l}\text { 夕、 、屋、代書屋、查室関係 } \\
\text { 左官、建築会社文店長、家具屋 }\end{array}$} \\
\hline & o & 4 (1) & $2(0.5)$ & $2(0.5)$ & $1(0.2)$ & $0 \quad(0)$ & $0 \quad(0)$ & \\
\hline \multirow{2}{*}{ 親 威 } & A & $48(12)$ & $30 \quad(7)$ & 24 (6) & $25 \quad(6)$ & $1(0,2)$ & $2(0.5)$ & \multirow{2}{*}{$\begin{array}{l}\text { 電気工事屋、左官、学生、 } \\
\text { 建築材料、建具屋、家具屋 }\end{array}$} \\
\hline & o & $28(6.5)$ & $18 \quad(4)$ & 4 (1) & $2(0.5)$ & $\begin{array}{ll}0 & (0)\end{array}$ & $2(0.5)$ & \\
\hline \multirow{2}{*}{ 知 人 } & A & $81(20)$ & 15 (3) & 43 (11) & 30 (7) & $2(0.5)$ & $1(0.2)$ & \multirow{2}{*}{$\begin{array}{l}\text { 建築設備の住事、家具屋、建築 } \\
\text { 籿料店、学生、役所、設計事務 } \\
\text { 所長 }\end{array}$} \\
\hline & o & $54(14)$ & $6(1.5)$ & 5 (1) & $1(0.2)$ & $0 \quad(0)$ & $1(0.2)$ & \\
\hline \multirow{2}{*}{ 計 } & A & $81(20)$ & 49 (12) & $80(20)$ & 57 (15) & $3(0.6)$ & $4 \quad(1)$ & \multirow{2}{*}{11} \\
\hline & 0 & $54(14)$ & $26 \quad(6)$ & 11 (2) & $4 \quad(1)$ & $\begin{array}{ll}0 & (0)\end{array}$ & $3(0.6)$ & \\
\hline & 計 & 135 & 75 & 9 & 61 & 3 & 7 & 19 \\
\hline & $\%$ & 34.5 & 19.1 & 23.3 & 15.5 & 0.7 & 1.7 & $100 \%$ \\
\hline
\end{tabular}
( )の内は\%であう。 が強く働いて居る事が何われた。(有意差

第 14 表 $(\%)$ の検定は $\chi^{2}$ 一検定で $P_{r}\left\{\chi^{2}>x_{0}{ }^{2}\right\}=$ 0.05 を以つて認められた)

§8. 両地域内居住者の住意識に 働く Communication 的役 割を持つ建築関係の仕事にた ずさわる人との人間関係と建 築業者への態度に就いて。

次の様な結果となつたが、この様な関係の中で特に目 立つ特性は、A地区では、結合関係の多い居から挙げて 見ると、(1) 大工 (親紫)、(2) 設計事務所関係（知人) (3) 役所関係、(4) 建築請負業 (親 嘁)、大工 (知人) の順になり、○地区では、（1）大工（親㑐）、（2）大 工 (知人)、(3) 建築請負業 (親墄)、(4) 同 (知人)、 (5) 設計事務所（知人）の順になつて居る。Spearman のの検定によつて順位づけの一致性を見た所 $\rho=$ $0.305, P_{r}\left\{\Sigma d_{i}{ }^{2}>d_{0}^{2}\right\}=0.425$ であるので一致はしてな 认。

右上の表は特に、〈良くつき合う〉くつき合う〉と いう評価の上に立つた結合関係であるから、これ等の接 触関係建築知識伝達の Communication の一つの大 きな役割として主要な条件である。次茟築業者への態 度を調べると調査項目としては、一般の人々が家を立て る際建築業者依依頼する場合、一切をまかした方が良 いか否かの質問を与えた所、次の様な結果となつた。

第一 15 表

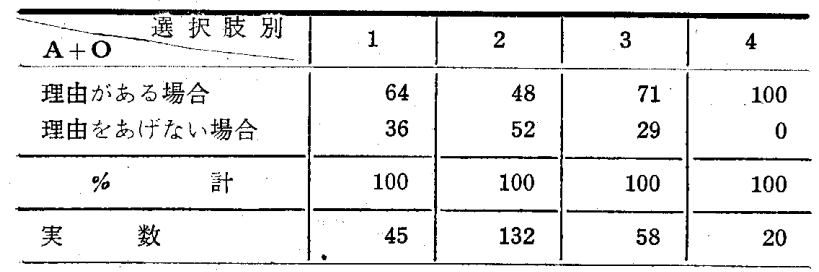

理由の女㚈、支げないの有意差険定 $\left(P_{r}\left\{\chi^{2}>\chi_{0}{ }^{2}\right\}=0.05\right.$

従つて、全部をなかせるという人は、決して技術的な面 よりる、人間関係の相手の信用といら問題と結びつけて 判断を下して居る。特に一部杂かした方が良いと云う人
は大部分間取りや計画は《理由：自分の家だから、自分 の財産だから、自分が使うのだから使い易くする為》以 上の理由に自分でやりたいと述べ、構造材料、造作は業 者になかすとら意見が圧倒的である。又建築家に対す る職業的取扱いは、Oでは<建築家 $=$ 大工＝請負師>と 末分化して扱引人が多いが（特に工場勤務者関係）、Aで ほ＜建築家〉と＜請負師＝大工>と分化して判断する人 と末分化扱う人とが同じ程度に、（A未 $=32 \% ， \mathrm{~A}$ 分 $=$ $27 \%$ ，O末 $=42 \%$ ，O分 $=12 \%: P_{r}\left\{x^{2}>\chi^{0}\right\}=0.10$ を以 つて有意差が認められる）特に分化して判断する人は経 営管理職や俸給生活者 (一般職負で特江設計関係の仕事 飞従事する人と接触する機会の多い人）に見られる。以 上総括的に云つて、都市住宅の地域性を強く規定する要 因は、職業的分布を背景とした社会階層の在り方、それ そ働くマス・コミ伝達性の関係、居住者の接触する人間 関係の条件、知識形成の在り方があり、特に住宅を財産 投資の対象として進める為に生ずる家相、格式への価値 の方向づけが重要な地域性を規定する要因として働く。 従つて、現象的にも内質的飞も共通して云学る事は居住 生活での“選択の仕方”や“決定の仕方”の価值規準を 以上の具体的な要因で構成して進められた結果が現象規 定に大きく働く事である。現在時の住居水準の在り方を 調べる際、その現象の変動の仕方も同時に必要とする時 は、常に、この様な変動化の決定の仕方が大きく㗢く事 からそれの在り方も同時汇把总る事が肝要である。終り 飞本研究に衩大建築学生失野雄司君の尽力を得た。こ こに感謝の意を表する。 